\title{
30. CHARACTERIZATION AND CORRELATION OF MEGASCOPIC TEPHRAS IN SITE 792 CORES FROM THE IZU-OGASAWARA FOREARC BASIN (JAPAN) BY TRACE ELEMENTS AND ${ }^{87} \mathrm{Sr} /{ }^{86} \mathrm{Sr}$ AND ${ }^{143} \mathrm{Nd} /{ }^{144} \mathrm{Nd}$ ISOTOPES ${ }^{1}$
}

\author{
Per Kristian Egeberg, ${ }^{2}$ Arild O. Brunfelt ${ }^{3}$ and Arne S. Stabel ${ }^{3}$
}

\begin{abstract}
Glass shards from 26 megascopic tephras (1-29 cm thick) were separated and analyzed for 26 elements and ${ }^{87} \mathrm{Sr} /{ }^{86} \mathrm{Sr}$ and ${ }^{143} \mathrm{Nd} /{ }^{144} \mathrm{Nd}$ isotope ratios. The isotope data allowed us to assess the degree of alteration of the samples. The separates contain less than $10 \%$ of palagonitized glass or secondary alteration minerals. Correlation diagrams and multivariate analyses have been used to characterize the glass shards in a tectonic setting and group the tephras according to their magmatic affinity. Four tholeiitic groups, two calc-alkaline groups, and one group with glass of shoshonitic affinity can be distinguished. The tholeiitic groups form a time series; however, judging from the rare-earth-element patterns and the temporal variations of the $\mathrm{Ce} / \mathrm{Yb}$ ratios, the evolution is not unidirectional from strong to weak tholeiitic affinity.

The tephras have been correlated with volcanism along the Izu-Ogasawara and Ryukyu arcs by means of trace element distribution, ${ }^{87} \mathrm{Sr} /{ }^{86} \mathrm{Sr}$ ratios, and their magmatic affinity. The tholeiitic layers were derived from volcanoes on the Izu-Ogasawara Arc, most probably from the volcanic island Hachijojima. Only one group of the calc-alkaline layers can have derived from the Izu-Ogasawara Arc. The other calc-alkaline layers and the two layers with shoshonitic affinity probably derive from volcanism along the Ryukyu Arc.
\end{abstract}

\section{INTRODUCTION}

The western Pacific has been characterized by extensive explosive volcanism throughout the Neogene. Documentation of the volcanic record has been obtained through the efforts of several Deep Sea Drilling Project/Ocean Drilling Program (DSDP/ODP) drillings in the Philippine Sea, along the Palau Kyushu Ridge, in the Nankai Trough and Shikoku Basin, and across the Mariana and Izu-Ogasawara arcs. Studies of ash layers from this area have focused mainly on sedimentological and volcano-chronological aspects, and several determinations of the major element composition of volcanic glasses have been reported (e.g., Furuta and Arai, 1980; Migdisov et al., 1981; Packham and Williams, 1982; Fujioka et al., 1986; Poulchet et al., 1986). However, only a very limited amount of data on trace elements and rare-earth elements (REEs) are available (e.g., Migdisov etal., 1981; Fujioka et al., 1986), and none of these discuss the degree of alteration of their samples. There are no published data on $\mathrm{Sr}$ isotopes of submarine volcanic ash layers from this region.

The main objectives of this study were to evaluate the extent of seawater alteration of the isolated volcanic glasses, to characterize their composition in a tectonic context, and to correlate the ash layers with volcanism along the Izu-Ogasawara Arc by means of trace element concentrations, REE patterns, and ${ }^{87} \mathrm{Sr} /{ }^{86} \mathrm{Sr}$ and ${ }^{143} \mathrm{Nd} /{ }^{144} \mathrm{Nd}$ isotope ratios.

\section{MATERIALS AND METHODS}

Site 792 is situated in the Izu-Ogasawara forearc basin southeast of the volcanic island Aogashima (Fig. 1). The geological setting has been described elsewhere (Taylor, Fujioka, et al., 1990). At Site 792 the Shipboard Scientific Party registered 200 ash layers from Hole $792 \mathrm{~A}$. In this study we have included 23 of these and an additional 3 from Hole 792E (Table 1). The ash layers were not indurated. We have numbered the layers from 1 to 26 , and for reference purposes Table 1

\footnotetext{
${ }^{1}$ Taylor, B., Fujioka, K., et al., 1992. Proc. ODP, Sci. Results, 126: College Station. TX (Ocean Drilling Program).

${ }^{2}$ Department of Geology, University of Oslo, P. O. Box 1047, Blindern, N-0316 Oslo 3. Norway (present address: Agder College, Tordenskjoldsgate 65, N-4604 Kristiansand. Norway).

${ }^{3}$ Mineralogisk-Geologisk Museum, Sarsgate 1, N-0562 Oslo 5, Norway.
}

also includes the numbers assigned to the ash layers from Hole 792A by the Shipboard Scientific Party (Taylor, Fujioka, et al., 1990).

\section{Isolation of Glass}

The samples (about $10 \mathrm{~cm}^{3}$ of wet sediment) were dispersed ultrasonically in distilled water, and the 63-125 $\mu \mathrm{m}$ size fraction was isolated by wet sieving. In some layers no glass particles were greater than $63 \mu \mathrm{m}$. Because the risk of contamination and alteration effects increase with decreasing particle size, these samples were discarded. After being cleaned with distilled water, the 63-125 $\mu \mathrm{m}$ size fractions were dried for 1 week at $160^{\circ} \mathrm{C}$. The density values of five samples that, by microscopic examination, proved to be clean samples of clear glass were determined, using a $0.7-\mathrm{g}$ sample and a $5.000-\mathrm{cm}^{3}$ pycnometer. The results are listed in Table 2.

The average density of $2.35 \mathrm{~g} / \mathrm{cm}^{3}$ is similar to that of cristobalite. Based on these results two solutions of sodium polytungstate of density 2.25 and $2.45 \mathrm{~g} / \mathrm{cm}^{3}$ were prepared for centrifugationassisted, gravitational separation of phillipsite and biogenic opal (density $1.7-2.2 \mathrm{~g} / \mathrm{cm}^{3}$ ) and crystalline silicates, alumino silicates, and carbonates (density greater than $2.5 \mathrm{~g} / \mathrm{cm}^{3}$ ).

Following heavy liquid separation, the glass separates were kept in the centrifuge tubes and rinsed with 10 volumes $\left(10-20 \mathrm{~cm}^{3}\right)$ of distilled water, two volumes of $1 \mathrm{~N}$ supra pure $\mathrm{HCl}$, and finally with 10 volumes of distilled water.

\section{Instrumental Neutron Activation Analyses}

After drying at $160^{\circ} \mathrm{C}$, two subsamples of $\sim 40 \mathrm{mg}$ from each layer were weighed in aluminum foil and irradiated for $24 \mathrm{hr}$ at $1.2 \times 10^{13} \mathrm{n} / \mathrm{cm}^{2}$ $\times s$ (at the Institute for Energy and Technology, Kjeller, Norway). Half of the subsamples were only exposed to epithermal irradiation by shielding with Cd (Steinnes, 1971). The samples were allowed to cool for 7 days and were counted four times during the following 1.5 months using the coaxial $\mathrm{Ge}(\mathrm{Li})$ detector, the planar $\mathrm{HpGe}$ detector, and a multichannel analyzer (at the Mineralogical and Geological Museum, Oslo, Norway). The United States Geological Survey standards BCR-1, BHVO-1, and MAG-1 were run with the samples. In addition, five splits of Sample 26 were run to determine the precision of the analyses (reported as relative standard deviation [Rel. std.\%] in Table 1). 


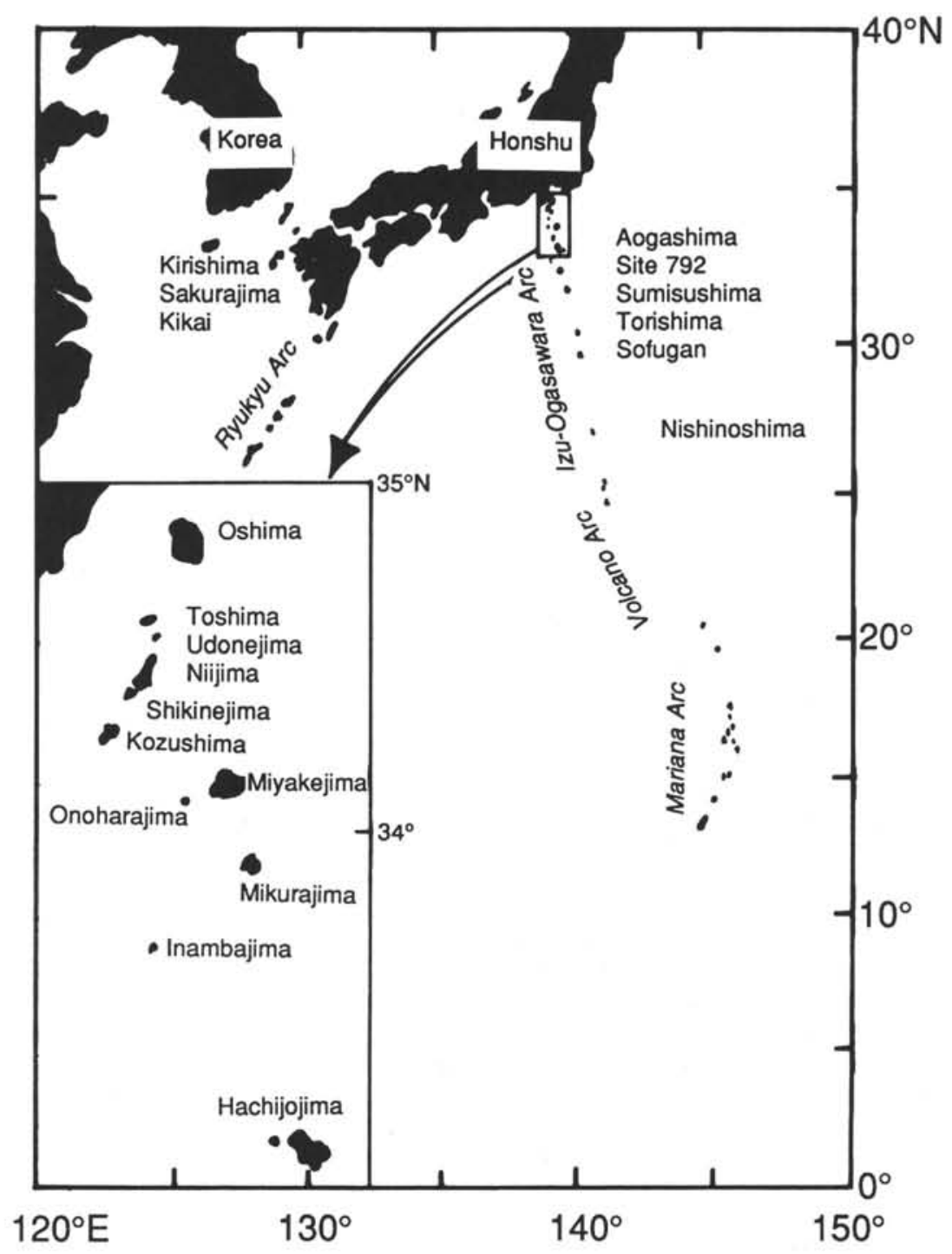

Figure 1. Locality map of the Izu-Ogasawara Arc.

\section{Rb-Sr and Sm-Nd Mass Spectrometry}

The separation of $\mathrm{Rb}, \mathrm{Sr}, \mathrm{Nd}$, and $\mathrm{Sm}$ from about 20-mg samples and mass spectrometric analyses were performed at the Geological Museum, University of Oslo, using standard ion exchange techniques and a Finnigan MAT 262 mass spectrometer in static mode (Nd), and a VG 354 machine in multicollector-dynamic mode ( $\mathrm{Sm}, \mathrm{Sr}$, and $\mathrm{Rb}$ ). The isotope dilution measurements were performed with the VG 354 machine in single-collector, peak-switching mode $(\mathrm{Rb}, \mathrm{Sr}, \mathrm{Nd}$, and $\mathrm{Sm})$. The techniques used in Oslo are described in detail by, for example, Mearns (1986) and Neumann et al. (1988). During the period of analysis, mean measured standard values were ${ }^{87} \mathrm{Sr} /{ }^{86} \mathrm{Sr}: \mathrm{NBS} 987 \mathrm{Sr}$ $=0.71024 \pm 0.00010 ;{ }^{143} \mathrm{Nd} /{ }^{144} \mathrm{Nd}$ : Johnson and Matthey C $321=$ $0.511108 \pm 0.000002$; and La Jolla Nd $=0.511851 \pm 0.000002$. The concentrations of $\mathrm{Sr}, \mathrm{Nd}, \mathrm{Sm}$, and $\mathrm{Rb}$ determined by isotope dilution are superior to the results obtained by INAA (standard deviations in Table 1).

\section{RESULTS AND DISCUSSION}

The number of chemical analyses of unaltered tephra is small compared with the enormous volume of published analyses of lavas.
This is because of (1) the ease by which the composition of tephra is changed by diagenetic alteration, (2) the difficulty of recognizing mixtures in tephras, and (3) the problem of sorting of the tephra components during transport. For these reasons, tephra composition has been used to a very limited extent for deciphering magma evolution. Yet pyroclastic fragments such as glass shards are unique because they quench almost instantly on eruption and are not subjected to crystal fractionation processes occurring in slowly cooling flows. The potential for high-resolution dating of marine tephra should make these very attractive targets for studies of short-wave temporal variations in magma composition of a given tectonic segment.

This discussion will focus on three aspects of the tephra geochemistry: (1) the degree of alteration of the glasses, (2) chemical characterization in a tectonic context, and (3) correlation of the tephra with volcanism along the Izu-Ogasawara Arc.

The analytical results are listed in Table 1, which also includes the relative standard deviation (Rel. std.\%), the depth of each layer in meters below seafloor (mbsf), and the approximate age (determined from the sediment accumulation curves prepared by the Shipboard Scientific Party on the basis of nannofossil and palaeomagnetic stratigraphy (Taylor, Fujioka, et al., 1990). No sample contained more than $41.6 \mathrm{ppm} \mathrm{W}$ and no element correlated significantly (at the $95 \%$ 
Table 1. Depth, thickness, and composition of selected ash layers, Holes 792A and 792E.

\begin{tabular}{|c|c|c|c|c|c|c|c|c|c|c|c|c|c|c|c|c|}
\hline $\begin{array}{l}\text { Core, section, } \\
\text { interval }(\mathrm{cm})\end{array}$ & Id & No. & $\begin{array}{l}\text { Depth } \\
\text { (mbsf) }\end{array}$ & $\begin{array}{c}\text { Age } \\
\text { (m.y.) }\end{array}$ & $\begin{array}{l}\text { Thickness } \\
(\mathrm{cm})\end{array}$ & $\begin{array}{l}\mathrm{Na}_{2} \mathrm{O} \\
(\%)\end{array}$ & $\begin{array}{c}\mathrm{Sc} \\
(\mathrm{ppm})\end{array}$ & $\begin{array}{l}\mathrm{TiO}_{2} \\
(\%)\end{array}$ & $\begin{array}{l}\mathrm{Fe}_{2} \mathrm{O}_{3} \\
(\%)\end{array}$ & $\begin{array}{c}\text { Co } \\
(\mathrm{ppm})\end{array}$ & $\begin{array}{c}\mathrm{Rb} \\
(\mathrm{ppm})\end{array}$ & $\begin{array}{c}\mathrm{Sr} \\
(\mathrm{ppm})\end{array}$ & $\underset{(\mathrm{ppm})}{\mathrm{Zr}}$ & $\underset{(\mathrm{ppm})}{\mathrm{Sb}}$ & $\underset{(\mathrm{ppm})}{\mathrm{Cs}}$ & $\begin{array}{c}\mathrm{Ba} \\
(\mathrm{ppm})\end{array}$ \\
\hline $\begin{array}{c}\text { 126-792A- } \\
\text { 1H-5, 33-35 } \\
1 \mathrm{H}-6,110-112 \\
2 \mathrm{H}-1,114-116 \\
2 \mathrm{H}-2,84-86 \\
3 \mathrm{H}-1,83-85 \\
3 \mathrm{H}-1,125-127 \\
3 \mathrm{H}-2,107-109 \\
4 \mathrm{H}-2,39-41 \\
4 \mathrm{H}-4,6-8 \\
4 \mathrm{H}-4,99-101 \\
5 \mathrm{H}-1,40-42 \\
5 \mathrm{H}-2,85-87 \\
5 \mathrm{H}-3,17-19 \\
5 \mathrm{H}-3,61-63 \\
5 \mathrm{H}-3,135-137 \\
6 \mathrm{H}-2,100-102 \\
7 \mathrm{H}-1,27-29 \\
7 \mathrm{H}-2,44-46 \\
7 \mathrm{H}-4,16-18 \\
8 \mathrm{H}-\mathrm{CC}, 2-4 \\
9 \mathrm{H}-3,47-49 \\
9 \mathrm{H}-4,11-13 \\
10 \mathrm{H}-3,38-40\end{array}$ & $\begin{array}{r}19 \\
25 \\
5 \\
34 \\
44 \\
46 \\
50 \\
75 \\
82 \\
88 \\
104 \\
112 \\
115 \\
118 \\
123 \\
129 \\
145 \\
149 \\
156 \\
173 \\
182 \\
191\end{array}$ & $\begin{array}{r}3 \\
4 \\
6 \\
7 \\
8 \\
9 \\
14 \\
16 \\
17 \\
18 \\
19 \\
20 \\
21 \\
22 \\
24 \\
26 \\
27 \\
29 \\
30 \\
31 \\
32 \\
33\end{array}$ & $\begin{array}{r}6.34 \\
8.61 \\
10.85 \\
12.05 \\
19.94 \\
20.36 \\
21.68 \\
30.30 \\
32.97 \\
33.90 \\
38.21 \\
40.16 \\
40.98 \\
41.42 \\
42.16 \\
49.71 \\
56.88 \\
58.55 \\
61.27 \\
75.40 \\
79.08 \\
80.22 \\
88.69\end{array}$ & $\begin{array}{l}0.08 \\
0.11 \\
0.13 \\
0.15 \\
0.25 \\
0.25 \\
0.27 \\
0.37 \\
0.41 \\
0.42 \\
0.47 \\
0.50 \\
0.51 \\
0.51 \\
0.52 \\
0.61 \\
0.70 \\
0.72 \\
0.73 \\
0.86 \\
0.89 \\
0.90 \\
0.97\end{array}$ & $\begin{array}{r}6 \\
29 \\
10 \\
10 \\
14 \\
5 \\
16 \\
13 \\
1 \\
9 \\
5 \\
9 \\
11 \\
6 \\
15 \\
19 \\
8 \\
11 \\
16 \\
9 \\
17 \\
12 \\
5\end{array}$ & $\begin{array}{l}4.00 \\
5.38 \\
4.46 \\
4.89 \\
5.26 \\
5.52 \\
2.96 \\
4.36 \\
5.68 \\
4.56 \\
5.29 \\
5.09 \\
5.20 \\
4.90 \\
4.45 \\
5.55 \\
5.78 \\
5.72 \\
5.91 \\
4.86 \\
3.82 \\
5.37\end{array}$ & $\begin{array}{r}11.2 \\
17.1 \\
27.0 \\
17.4 \\
14.2 \\
9.7 \\
8.6 \\
11.8 \\
20.9 \\
20.9 \\
12.1 \\
12.4 \\
22.3 \\
23.3 \\
4.0 \\
15.7 \\
13.5 \\
14.9 \\
17.9 \\
4.1 \\
14.1 \\
18.5 \\
20.2\end{array}$ & $\begin{array}{l}0.53 \\
0.31 \\
0.56 \\
0.48 \\
0.24 \\
0.14 \\
0.32 \\
0.46 \\
0.40 \\
0.39 \\
0.17 \\
0.21 \\
0.39 \\
0.44 \\
0.15 \\
0.21 \\
0.14 \\
0.31 \\
0.29 \\
0.18 \\
0.36 \\
0.47 \\
0.34\end{array}$ & $\begin{array}{l}3.68 \\
2.92 \\
5.72 \\
3.11 \\
2.15 \\
1.81 \\
2.09 \\
3.32 \\
4.00 \\
3.67 \\
2.37 \\
2.25 \\
3.14 \\
3.15 \\
1.20 \\
2.74 \\
2.04 \\
2.61 \\
3.09 \\
0.94 \\
2.64 \\
4.31 \\
2.20\end{array}$ & $\begin{array}{l}3.5 \\
2.2 \\
5.1 \\
2.7 \\
1.8 \\
1.3 \\
2.0 \\
4.0 \\
4.1 \\
2.3 \\
1.0 \\
2.1 \\
2.1 \\
2.9 \\
0.9 \\
0.8 \\
0.6 \\
1.3 \\
1.9 \\
0.6 \\
2.7 \\
4.2 \\
0.7\end{array}$ & $\begin{array}{r}12.8 \\
11.1 \\
9.2 \\
63.9 \\
12.6 \\
23.6 \\
13.3 \\
13.1 \\
17.2 \\
6.6 \\
21.7 \\
14.6 \\
6.0 \\
7.3 \\
99.8 \\
14.6 \\
14.4 \\
14.4 \\
14.5 \\
112.4 \\
47.4 \\
14.3 \\
11.9\end{array}$ & $\begin{array}{r}134.2 \\
113.0 \\
155.4 \\
141.0 \\
86.4 \\
52.7 \\
90.1 \\
69.0 \\
115.8 \\
110.2 \\
80.7 \\
68.0 \\
116.8 \\
117.8 \\
82.7 \\
81.2 \\
77.4 \\
101.6 \\
131.3 \\
83.2 \\
106.6 \\
121.3 \\
84.6\end{array}$ & $\begin{array}{l}135 \\
151 \\
112 \\
186 \\
136 \\
156 \mathrm{tn} \\
114 \\
227 \\
173 \\
116 \\
256 \\
153 \\
90 \\
120 \\
113 \\
200 \\
228 \\
184 \\
266 \\
88 \\
163 \\
138 \\
193\end{array}$ & $\begin{array}{l}0.20 \\
0.13 \\
0.14 \\
0.17 \\
0.28 \\
0.20 \\
0.31 \\
0.40 \\
0.23 \\
0.36 \\
0.05 \\
0.37 \\
0.20 \\
0.21 \\
0.59 \\
0.09 \\
0.08 \\
0.14 \\
0.06 \\
0.43 \\
0.66 \\
0.21 \\
0.09\end{array}$ & $\begin{array}{l}0.85 \\
0.79 \\
0.96 \\
2.84 \\
1.00 \\
0.93 \\
1.28 \\
1.83 \\
1.02 \\
0.92 \\
0.89 \\
1.49 \\
0.61 \\
0.58 \\
7.04 \\
0.57 \\
0.58 \\
0.48 \\
0.74 \\
7.59 \\
2.60 \\
0.95 \\
0.60\end{array}$ & $\begin{array}{l}205 \\
175 \\
223 \\
344 \\
243 \\
273 \\
232 \\
312 \\
229 \\
241 \\
213 \\
265 \\
179 \\
190 \\
471 \\
162 \\
175 \\
186 \\
242 \\
571 \\
478 \\
205 \\
189\end{array}$ \\
\hline Rel. Std. (\%) & & & & & & 5.4 & 2.3 & 9.9 & 2.1 & 1.9 & 0.03 & 0.03 & 9.02 & 25.76 & 7.01 & 4.75 \\
\hline
\end{tabular}

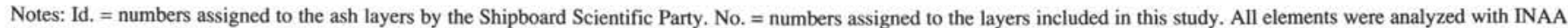
except Rb, Sr, Nd, and Sm, which were determined by isotopic dilution. The age of the layers was determined from the sediment accumulation curves prepared by the Shipboard Scientific Party on the basis of nannofossil and paleomagnetic stratigraphy.

confidence level) with $\mathrm{W}$. This indicates that the cleaning procedure reduced contamination from the heavy liquid (sodium polytungstate) to a minimum for all elements except $\mathrm{W}$.

Fujioka et al. (this volume) and Rodolfo et al. (this volume) discriminate between clear, brown, and opaque glass fragments. The gravitational separation procedure effectively isolates the clear glasses, and no sample contained more than $5 \%$ brown and opaque glass fragments.

\section{Degree of Alteration of the Glasses}

Volcanic glass is thermodynamically unstable and decomposes more readily than nearly all associated phases. The breakdown of volcanic glasses is not congruent; therefore alteration leads to compositional changes that may overprint the original compositional variations of main interest in this study.

Alteration of basaltic glass under marine conditions is fairly well documented (e.g., Furnes, 1980; Ailin-Pyzik and Sommer, 1981; Staudigel and Hart, 1983), and includes conservation of Fe and $\mathrm{Ti}$ (Furnes observed loss of $\mathrm{Ti}$ ) and loss of all other major elements except $\mathrm{K}$. Some elements, in particular $\mathrm{Rb}$ and $\mathrm{Cs}$, show strong enrichment during alteration. The alteration of silicic glass differs from the alteration of basaltic glass in many ways. The initial stage involves diffusion-controlled hydration and alkali ion exchange but only minor overall chemical changes. This is commonly followed by a stage of glass matrix destruction and precipitation of secondary phases (Fisher and Schmincke, 1984). The clay-altered silicic ash is also enriched in $\mathrm{Fe}$ and $\mathrm{Ti}$; in contrast to altered basaltic glass, it is depleted in $\mathrm{Cs}, \mathrm{K}$, and $\mathrm{Rb}$, however. Given this background, the positive correlation between $\mathrm{TiO}_{2}$ and $\mathrm{Fe}_{2} \mathrm{O}_{3}$ (Fig. 2) need not be an igneous trend; rather, it could be the result of seawater alteration and/or inclusion of secondary alteration products.

Seawater/basaltic glass interactions gave rise to a considerable exchange of $\mathrm{Sr}$ (Staudigel and Hart, 1983), and the alteration products formed from silicic glass were enriched in $\mathrm{Sr}$ (Zielinski, 1982). The ${ }^{87} \mathrm{Sr} /{ }^{86} \mathrm{Sr}$ ratio of arc-derived volcanic material $(0.703-0.705)$ is quite different from that of Quaternary seawater $(0.7090-0.7092)$. The $\mathrm{Sr} / \mathrm{Nd}$ concentration ratio of seawater is about $2.0 \pm 10^{5}$ times greater than in arc-derived volcanic products. Thus, seawater alteration reac- tions will have a strong impact on the ${ }^{87} \mathrm{Sr} /{ }^{86} \mathrm{Sr}$ ratio but will leave the ${ }^{143} \mathrm{Nd} /{ }^{144} \mathrm{Nd}$ ratio of the glass samples virtually unchanged.

During exchange with seawater, the evolution of the ${ }^{143} \mathrm{Nd} /{ }^{144} \mathrm{Nd}$ isotope ratio of the glass is related to the evolution of the ${ }^{87} \mathrm{Sr} /{ }^{86} \mathrm{Sr}$ isotope ratio of the glass through Equation 1:

$$
\begin{gathered}
\left(\frac{{ }^{143} \mathrm{Nd}}{{ }^{144} \mathrm{Nd}}\right)_{g}=\frac{\left({ }^{87} \mathrm{Sr} /{ }^{\beta 6} \mathrm{Sr}\right)_{g}-\left({ }^{87} \mathrm{Sr} /{ }^{\beta 6} \mathrm{Sr}\right)_{g i}}{\left({ }^{87} \mathrm{Sr} /{ }^{6} \mathrm{Sr}\right)_{s w}-\left({ }^{87} \mathrm{Sr} /{ }^{6} \mathrm{Sr}\right)_{g i}} \times \frac{(\mathrm{Sr} / \mathrm{Nd})_{g}}{(\mathrm{Sr} / \mathrm{Nd})_{s w}} \times \\
{\left[\left({ }^{143} \mathrm{Nd} /{ }^{144} \mathrm{Nd}\right)_{s w}-\left({ }^{143} \mathrm{Nd} /{ }^{44} \mathrm{Nd}\right)_{g i}\right]+\left({ }^{143} \mathrm{Nd} /{ }^{144} \mathrm{Nd}\right)_{g i},}
\end{gathered}
$$

where $g$, gi, and $s w$ denote altered glass, initial glass, and seawater respectively.

On a ${ }^{143} \mathrm{Nd} /{ }^{144} \mathrm{Nd}$ vs. ${ }^{87} \mathrm{Sr} /{ }^{86} \mathrm{Sr}$ diagram, all our observations plot inside or very close to the mantle array (Fig. 3). The isotope ratios of the glasses are similar to the values reported for basalts from the same area. We take this as an indication that the separates do not contain appreciable amounts of palagonitized glass or secondary alteration products. However, the seawater alteration line does allow for about $10 \%$ exchange of $\mathrm{Sr}$ for a few samples. The fact that the samples define a line parallel to the mantle array indicates that even the samples with the most radiogenic $\mathrm{Sr}$-isotope ratios $(0.7050-0.7052)$ do not contain significant amounts of palagonitized glass or secondary alteration products. Figure 3 indicates the presence of at least three different glass populations. This will be discussed further below.

\section{Chemical Characterization of the Glasses}

Several different schemes have been used to classify and discriminate between magmas of different tectonic settings. The $\mathrm{La} / \mathrm{Ta}$ ratios of the samples (Fig. 4) are close to that found for island-arc tholeiites and calc-alkaline lavas from Japan (Joron and Treuil, 1977; Wood et al., 1979) and are quite distinct from that of $\mathrm{N}$ - and E-type mid-ocean ridge basalts (MORBs). On the Th-Hf-Ta diagram (Fig. 5), all samples plot in the field of destructive plate-margin basalts and differentiates as defined by Wood (1980). These observations further support our contention that the glasses represent unaltered samples of island-arc volcanism. The samples span the entire calc-alkaline and tholeiitic 
Table 1 (continued).

\begin{tabular}{|c|c|c|c|c|c|c|c|c|c|c|c|c|c|c|c|c|}
\hline$\underset{(\mathrm{ppm})}{\mathrm{La}}$ & $\begin{array}{c}\mathrm{Ce} \\
(\mathrm{ppm})\end{array}$ & $\underset{(\mathrm{ppm})}{\mathrm{Nd}}$ & $\underset{(\mathrm{ppm})}{\mathrm{Sm}}$ & $\underset{(\mathrm{ppm})}{\mathrm{Eu}}$ & $\begin{array}{c}\mathrm{Tb} \\
(\mathrm{ppm})\end{array}$ & $\begin{array}{c}\mathrm{Ho} \\
(\mathrm{ppm})\end{array}$ & $\underset{(\mathrm{ppm})}{\mathrm{Tm}}$ & $\underset{(\mathrm{ppm})}{\mathrm{Yb}}$ & $\underset{(\mathrm{ppm})}{\mathrm{Lu}}$ & $\underset{(\mathrm{ppm})}{\mathrm{Hf}}$ & $\begin{array}{c}\mathrm{Ta} \\
(\mathrm{ppm})\end{array}$ & $\underset{(\mathrm{ppm})}{\mathrm{W}}$ & $\begin{array}{c}\text { Th } \\
(\mathrm{ppm})\end{array}$ & $\underset{(\mathrm{ppm})}{\mathrm{U}}$ & ${ }^{87} \mathrm{Sr} /{ }^{86} \mathrm{Sr}$ & ${ }^{143} \mathrm{Nd} / /^{144} \mathrm{Nd}$ \\
\hline $\begin{array}{r}13.0 \\
7.2 \\
5.2 \\
21.2 \\
6.0 \\
13.9 \\
2.5 \\
4.9 \\
8.1 \\
4.5 \\
14.2 \\
6.8 \\
3.6 \\
4.1 \\
24.0 \\
11.3 \\
13.3 \\
11.5 \\
12.0 \\
30.1 \\
13.4 \\
6.6 \\
8.6\end{array}$ & $\begin{array}{l}14.6 \\
18.0 \\
10.4 \\
40.2 \\
9.6 \\
31.7 \\
15.1 \\
16.5 \\
13.8 \\
13.6 \\
34.4 \\
13.3 \\
14.3 \\
14.7 \\
46.4 \\
25.4 \\
26.1 \\
22.0 \\
31.8 \\
45.1 \\
41.4 \\
21.0 \\
27.3\end{array}$ & $\begin{array}{l}12.4 \\
12.3 \\
11.2 \\
23.1 \\
12.5 \\
16.5 \\
12.1 \\
11.8 \\
19.8 \\
11.7 \\
23.2 \\
13.8 \\
10.5 \\
10.8 \\
16.9 \\
21.7 \\
22.2 \\
17.9 \\
19.9 \\
15.0 \\
14.8 \\
13.8 \\
18.7\end{array}$ & $\begin{array}{l}4.01 \\
3.75 \\
3.91 \\
5.55 \\
3.93 \\
4.24 \\
3.81 \\
4.41 \\
6.00 \\
4.31 \\
6.04 \\
4.50 \\
3.83 \\
3.92 \\
3.25 \\
6.41 \\
6.21 \\
5.93 \\
5.75 \\
3.17 \\
4.50 \\
4.33 \\
5.70\end{array}$ & $\begin{array}{l}1.06 \\
1.01 \\
1.50 \\
1.34 \\
1.12 \\
0.71 \\
0.89 \\
1.17 \\
1.36 \\
1.36 \\
1.38 \\
0.77 \\
1.32 \\
1.35 \\
0.54 \\
1.68 \\
1.64 \\
1.43 \\
2.12 \\
0.62 \\
1.04 \\
1.44 \\
1.32\end{array}$ & $\begin{array}{l}0.97 \\
0.88 \\
1.05 \\
1.01 \\
0.92 \\
0.89 \\
0.90 \\
1.32 \\
1.20 \\
1.18 \\
1.28 \\
1.14 \\
1.09 \\
1.03 \\
0.53 \\
1.46 \\
1.32 \\
1.37 \\
0.51 \\
0.98 \\
1.02 \\
1.37\end{array}$ & $\begin{array}{l}1.42 \\
0.99 \\
1.79 \\
1.35 \\
1.17 \\
1.14 \\
1.36 \\
2.15 \\
1.83 \\
1.93 \\
1.68 \\
1.91 \\
1.41 \\
1.31 \\
0.53 \\
1.66 \\
1.74 \\
1.60 \\
1.78 \\
0.71 \\
1.37 \\
1.29 \\
1.54\end{array}$ & $\begin{array}{l}0.45 \\
0.45 \\
0.54 \\
0.66 \\
0.45 \\
0.46 \\
0.47 \\
0.73 \\
0.66 \\
0.52 \\
0.64 \\
0.53 \\
0.45 \\
0.51 \\
0.43 \\
0.70 \\
0.72 \\
0.72 \\
0.83 \\
0.35 \\
0.44 \\
0.52 \\
0.70\end{array}$ & $\begin{array}{l}4.45 \\
4.45 \\
5.00 \\
4.43 \\
5.09 \\
5.02 \\
4.78 \\
6.97 \\
6.21 \\
5.67 \\
6.52 \\
5.55 \\
5.32 \\
5.22 \\
2.85 \\
7.13 \\
6.49 \\
6.07 \\
7.32 \\
2.53 \\
4.92 \\
5.14 \\
6.63\end{array}$ & $\begin{array}{l}0.70 \\
0.85 \\
0.74 \\
0.66 \\
0.83 \\
1.18 \\
0.68 \\
0.77 \\
1.35 \\
1.06 \\
0.90 \\
1.18 \\
1.04 \\
0.88 \\
0.51 \\
1.22 \\
1.30 \\
1.18 \\
0.20 \\
0.93 \\
0.64 \\
1.09\end{array}$ & $\begin{array}{l}3.27 \\
3.46 \\
2.91 \\
4.97 \\
3.74 \\
4.99 \\
3.97 \\
5.71 \\
4.43 \\
3.07 \\
6.54 \\
4.44 \\
3.05 \\
2.84 \\
3.71 \\
5.61 \\
5.51 \\
5.66 \\
6.09 \\
2.93 \\
4.76 \\
4.01 \\
4.79\end{array}$ & $\begin{array}{l}0.12 \\
0.13 \\
0.11 \\
0.63 \\
0.10 \\
0.38 \\
0.10 \\
0.13 \\
0.24 \\
0.07 \\
0.47 \\
0.11 \\
0.07 \\
0.07 \\
0.70 \\
0.32 \\
0.37 \\
0.31 \\
0.34 \\
0.86 \\
0.32 \\
0.18 \\
0.25\end{array}$ & $\begin{array}{r}34.2 \\
30.1 \\
29.1 \\
25.5 \\
14.3 \\
39.2 \\
13.3 \\
15.4 \\
21.5 \\
21.4 \\
9.4 \\
12.0 \\
10.3 \\
41.6 \\
19.8 \\
8.4 \\
6.3 \\
12.1 \\
14.0 \\
14.2 \\
11.7 \\
13.6 \\
10.0\end{array}$ & $\begin{array}{r}0.71 \\
0.54 \\
0.59 \\
6.99 \\
0.73 \\
1.81 \\
0.74 \\
0.75 \\
1.05 \\
0.19 \\
2.11 \\
0.70 \\
0.29 \\
0.28 \\
9.50 \\
1.12 \\
1.30 \\
1.17 \\
1.43 \\
10.72 \\
5.00 \\
0.97 \\
1.05\end{array}$ & $\begin{array}{l}0.43 \\
0.26 \\
0.32 \\
1.65 \\
0.34 \\
0.70 \\
0.41 \\
0.60 \\
0.56 \\
0.31 \\
0.76 \\
0.53 \\
0.15 \\
0.28 \\
1.88 \\
0.39 \\
0.54 \\
0.52 \\
0.59 \\
2.86 \\
1.23 \\
0.43 \\
0.44\end{array}$ & $\begin{array}{l}0.70360 \\
0.70347 \\
0.70398 \\
0.70527 \\
0.70348 \\
0.70326 \\
0.70349 \\
0.70372 \\
0.70404 \\
0.70372 \\
0.70315 \\
0.70374 \\
0.70376 \\
0.70374 \\
0.70510 \\
0.70259 \\
0.70317 \\
0.70323 \\
0.70333 \\
0.70502 \\
0.70434 \\
0.70343 \\
0.70346\end{array}$ & $\begin{array}{l}0.51308 \\
0.51306 \\
0.51304 \\
0.51260 \\
0.51310 \\
0.51300 \\
0.51307 \\
0.51309 \\
0.51305 \\
0.51311 \\
0.51306 \\
0.51307 \\
0.51310 \\
0.51308 \\
0.51260 \\
0.51305 \\
0.51306 \\
0.51306 \\
0.51304 \\
0.51260 \\
0.51281 \\
0.51302 \\
0.51303\end{array}$ \\
\hline $\begin{array}{r}12.3 \\
22.3 \\
4.5\end{array}$ & $\begin{array}{l}21.2 \\
44.5 \\
14.6\end{array}$ & $\begin{array}{l}15.0 \\
17.6 \\
12.1\end{array}$ & $\begin{array}{l}3.89 \\
4.27 \\
4.05\end{array}$ & $\begin{array}{l}0.84 \\
0.41 \\
1.31\end{array}$ & $\begin{array}{l}0.83 \\
0.88 \\
1.03\end{array}$ & $\begin{array}{l}1.34 \\
1.04 \\
1.55\end{array}$ & $\begin{array}{l}0.42 \\
0.56 \\
0.57\end{array}$ & $\begin{array}{l}4.41 \\
4.74 \\
5.67\end{array}$ & $\begin{array}{l}0.87 \\
1.09 \\
1.21\end{array}$ & $\begin{array}{l}4.57 \\
4.70 \\
3.26\end{array}$ & $\begin{array}{l}0.36 \\
0.45 \\
0.09\end{array}$ & $\begin{array}{l}15.8 \\
26.6 \\
31.8\end{array}$ & $\begin{array}{l}1.68 \\
7.09 \\
0.61\end{array}$ & $\begin{array}{l}0.65 \\
1.71 \\
0.39\end{array}$ & $\begin{array}{l}0.70331 \\
0.70495 \\
0.70373\end{array}$ & $\begin{array}{l}0.51304 \\
0.51274 \\
0.51248\end{array}$ \\
\hline 6.64 & 12.4 & 0.05 & 0.05 & 2.04 & 0.80 & 5.00 & 1.78 & 1.86 & 9.83 & 2.42 & 1.58 & 10.60 & 3.38 & 12.90 & 0.0019 & 0.00075 \\
\hline
\end{tabular}

Table 2. Density of selected ash layers from Site 792.

\begin{tabular}{cc}
\hline $\begin{array}{c}\text { Layer } \\
\text { no. }\end{array}$ & $\begin{array}{c}\text { Density } \\
\left(\mathrm{g} / \mathrm{cm}^{3}\right)\end{array}$ \\
\hline 7 & 2.35 \\
8 & 2.31 \\
14 & 2.38 \\
18 & 2.39 \\
26 & 2.33 \\
\hline
\end{tabular}

bers given in Table 1. fields, and there are also indications of several other populations, one of intermediate composition and several of tholeiitic affinity.

Identification of those ash layers that may derive from the same source is interesting both for correlation purposes and because it can provide a clue to how arc-magmas evolve. In an attempt to identify those layers that have the most similar source, we have run a cluster analysis. Because we are mainly interested in primary compositional differences, only the more-hygromagmatophile (HYG; Wood et al., 1979) element ratios ( $\mathrm{Cs} / \mathrm{Rb}, \mathrm{Ba} / \mathrm{Rb}, \mathrm{La} / \mathrm{Rb}, \mathrm{Ce} / \mathrm{Rb}, \mathrm{Ta} / \mathrm{Rb}, \mathrm{Th} / \mathrm{Rb}$, and $\mathrm{U} / \mathrm{Rb}$ ) were used as inputs. The concentration of each element was divided by the concentration of $\mathrm{Rb}$, and the average of this ratio for all the samples was subtracted. This difference was then divided by the concentration of the element (so not to give undue weight to the most abundant elements). $\mathrm{Rb}$ was chosen because it was determined with best precision (Table 1). The results are presented as a dendogram (Fig. 6).

All clustering techniques involve a certain degree of subjectivity in deciding on the clustering level. The layers cluster into seven groups, and one layer (17) remains ungrouped (Fig. 6). To examine the significance of this clustering, the data were plotted in the Th-Ta$\mathrm{Yb}$ diagram determined by Pearce et al. (1981) (Fig. 7). In this diagram two samples exhibit shoshonitic affinities (Cluster 1, Fig. 6); there are two groups in the calc-alkaline field (Clusters 2 and 6) and

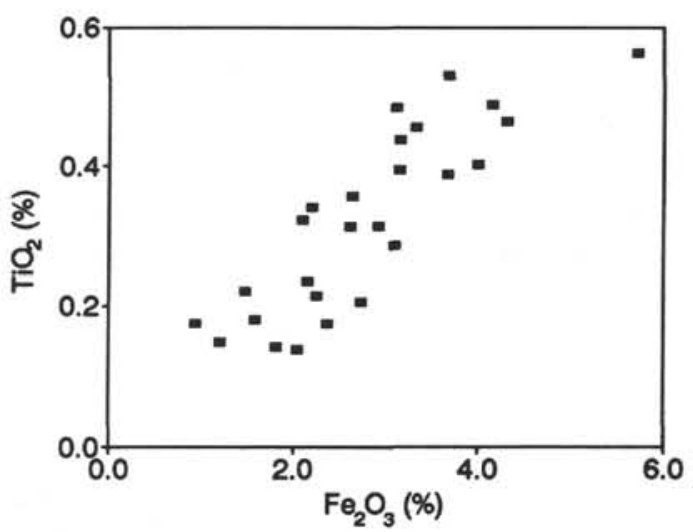

Figure 2. Percentages of $\mathrm{TiO}_{2}$ vs. $\mathrm{Fe}_{2} \mathrm{O}_{3}$ in glass shards isolated from tephras in Holes 792A and 792E.

four tholeiitic groups (Cluster 3, 4,5, and 7); and the single ungrouped layer is characterized by low $\mathrm{Ta} / \mathrm{Yb}$ and $\mathrm{Th} / \mathrm{Yb}$ ratios. We do not have full major element analyses to confirm the classification of the layers into shoshonitic, calc-alkaline, and tholeiitic groups; nevertheless, for the purpose of reference and simplification of the following discussion, we will refer to the layers as shoshonitic, calc-alkaline, and tholeiitic with the subdivisions shown in Figures 6 and 7 and Table 3.

Comparing Figures 6 and 7 reveals the presence of the same groups. When the full "more-HYG" signatures are compared, calcalkaline group $\mathrm{C} 2$ has a larger affinity toward the tholeitic groups than toward the other calc-alkaline group.

There are two different interpretations of the grouping of the layers: (1) that each group represents ash layers derived from one volcano or a suite of volcanoes fed by magma of similar composition (these volcanoes may be distributed along the arc) and, (2) that each group represents a particular stage of arc magma evolution and that the layers in each group may derive from several different volcanoes. If the maturation of the arc was synchronous along the segment of the arc that fed tephras to Site 792, then the second interpretation predicts temporal separation of the groups. Figure 8 shows that, indeed, except for one layer in T1, the tholeiitic groups are separated in time. This 


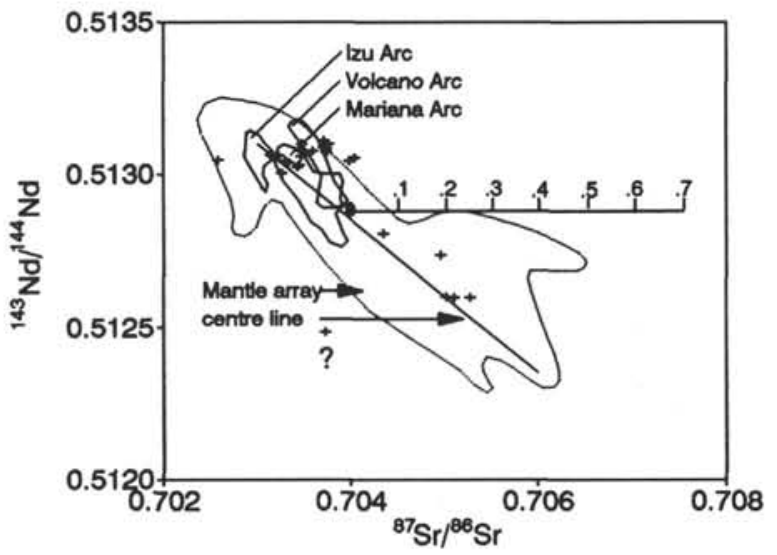

Figure 3. Isotopic ratios of $\mathrm{Nd}$ and $\mathrm{Sr}$ in glass shards isolated from tephras in Holes 792A and 792E. The point marked with "?" is regarded as suspicious, but the material was insufficient to repeat the analyses. Data from the IzuOgasawara, Volcano, and Mariana arcs were taken from Lin et al. (1990) and Hochstaedter et al. (1990). The seawater alteration line (divided into fraction of Sr exchanged) was estimated with Equation 1 (see text) and the following conditions for seawater: $\mathrm{Sr}=8 \mathrm{ppm}, \mathrm{Nd}=2.6 \pm 10^{-6} \mathrm{ppm},{ }^{87} \mathrm{Sr} /{ }^{86} \mathrm{Sr}=0.70906$, and ${ }^{143} \mathrm{Nd} /{ }^{144} \mathrm{Nd}=0.51245$. The following conditions apply for glass: $\mathrm{Sr}=100$ $\mathrm{ppm}, \mathrm{Nd}=15 \mathrm{ppm},{ }^{87} \mathrm{Sr} /{ }^{86} \mathrm{Sr}=0.704$, and ${ }^{143} \mathrm{Nd} /{ }^{144} \mathrm{Nd}=0.51288$.

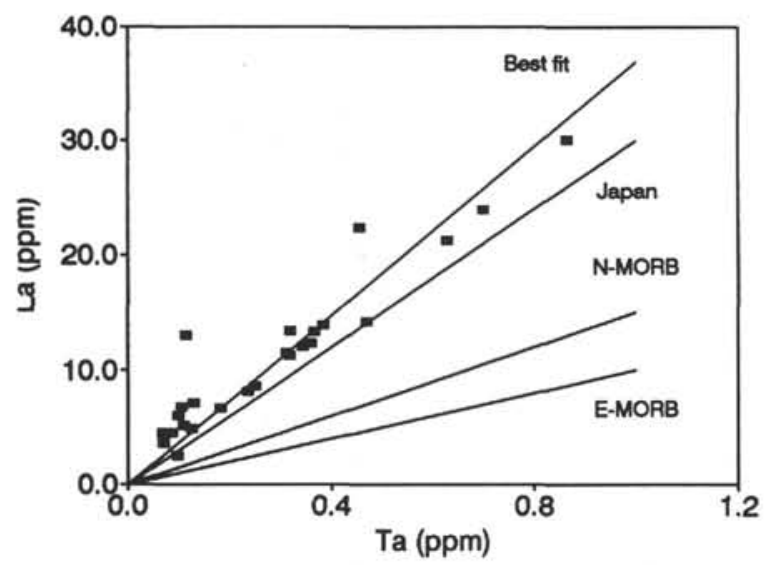

Figure 4. La vs. Ta in glass shards isolated from tephras in Holes 792A and $792 \mathrm{E}$. Lines for Japanese island-arc tholeiites and calc-alkaline lavas as well as N- and E-type MORBs are taken from Wood et al. (1979).

indicates that the second interpretation is correct but does not exclude the first interpretation. During the last $1 \mathrm{~m} . y$. , the composition of the tholeiitic arc volcanism might have changed from $\mathrm{T} 1$ through $\mathrm{T} 4$ and T3 and into T2 (Fig. 8).

The large-ion-lithophile-high-field-strength (LIL-HFS) diagram (Fig. 9A) shows that the indicated evolution from the oldest (T1) to the most recent group (T2) is unidirectional only for $\mathrm{Tb}$ and $\mathrm{Yb}$. For the remaining elements the evolution appears to be better described as a cyclic process. The same picture emerges from the rare-earth patterns (Fig. 10A). The two temporally most distant groups (T2 and T1) are more similar to each other than to any of the intermediate groups.

The view is generally held (e.g., Jakes and White, 1972) that early arc volcanism is characterized by tholeiitic series that grade into calc-alkaline series with increasing age. This shift in magma affinity takes tens of million of years. Based on the temporal distribution of the groups (Fig. 8), the rare-earth patterns (Fig. 10A) represent an evolution from less tholeiitic (T1) to more tholeiitic (T4 and T3)

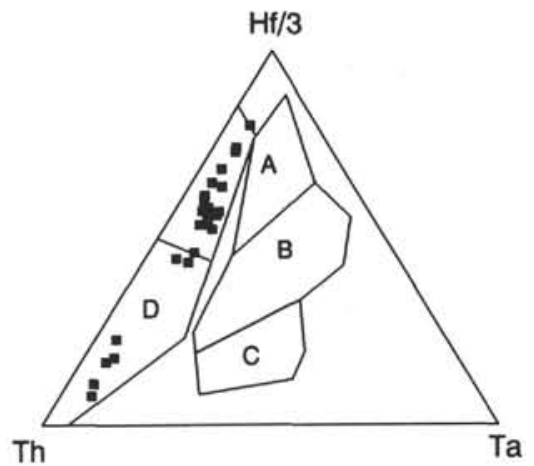

Figure 5. Th-Hf-Ta data on glass shards isolated from tephras in Holes 792A and $792 \mathrm{E}$ (after Wood, 1980). $\mathrm{A}=\mathrm{N}-\mathrm{MORB}, \mathrm{B}=\mathrm{E}-\mathrm{MORB}, \mathrm{C}=$ within-plate basalts, and $\mathrm{D}=$ active-plate margins.

volcanism and then a return to less tholeiitic volcanism (T2). This apparent discrepancy between the generally accepted linear model and the cyclic evolution found here may be taken as evidence that the $\mathrm{T} 2$ group layers do not belong to the same line of evolution as the $\mathrm{T} 1$, T3, and T4 group layers. A more detailed look at the evolution of the $\mathrm{Ce} / \mathrm{Yb}$-ratio (Fig. 11) may be taken as a support of this hypothesis. The rate and direction of inferred magma evolution is quite constant from 1 to $0.2 \mathrm{~m}$.y. when an abrupt reversal of the trend occurred. However, in a study of ash layers from North Pacific arcs, Scheidegger et al. (1980) observed rapid transitions between calc-alkaline and tholeiitic affinities during the last $2 \mathrm{~m}$.y. These short time fluctuations may represent noise superimposed on the long-term transition from tholeiitic toward calc-alkaline volcanism. A comprehensive discussion of the temporal trends is beyond the scope of this presentation.

The strong Ti depletion (Figs. 9A and 9B) is similar for all groups and underlines the importance of the crystallization of $\mathrm{Fe}$ and $\mathrm{Ti}$ oxides, hence the positive correlation between $\mathrm{Fe}$ and $\mathrm{Ti}$ (Fig. 2). However, the strong Ta depletion is unique for the tholeiitic layers and may indicate different modes of Ti removal in the calc-alkaline and shoshonitic systems.

The calc-alkaline and shoshonitic groups exhibit strong light-rareearth-element (LREE) enrichment (Fig. 10B) with $\mathrm{Ce} / \mathrm{Yb}$ ratios increasing systematically from 5.5 to 17.0 as one moves through the calc-alkaline field and into the shoshonitic field (Fig. 7).

\section{Source Correlation}

As revealed by the distribution of ash layers (e.g., Kennett, 1981; Machida, 1981), the atmospheric circulation over Japan and the surrounding oceans was dominated by westerly winds throughout the Quaternary. Site 792 is situated on the western flank of the volcanic front; thus, most probably the layers are derived from volcanoes on the arc itself. However, considering the widespread tephras produced by some volcanoes (Machida, 1981), derivation from the mainland or even the Ryukyu Arc cannot be excluded. The probability of local derivation increases with increasing layer thickness. The average thickness of the layers included in this study is about $10 \mathrm{~cm}$; only two layers are less than $5 \mathrm{~cm}$, and the thinnest is $1 \mathrm{~cm}$ (Layer 16, Table 1). Also, increasing particle size favors local derivation. We have only included layers containing more than about $100 \mathrm{mg} / 10 \mathrm{~cm}^{3}$ (wet sample) of glass particles in the 63-125 $\mu \mathrm{m}$ size range.

The layers cover the entire range of high $\mathrm{SiO}_{2}$ island-arc volcanism from tholeiitic to calc-alkaline and shoshonitic series. The view is generally held (e.g., Jakes and White, 1972) that these series are related both laterally and stratigraphically. The tholeiitic series represent immature island-arc volcanism that grades into calc-alkaline and shoshonitic series with increasing age and distance from the volcanic 


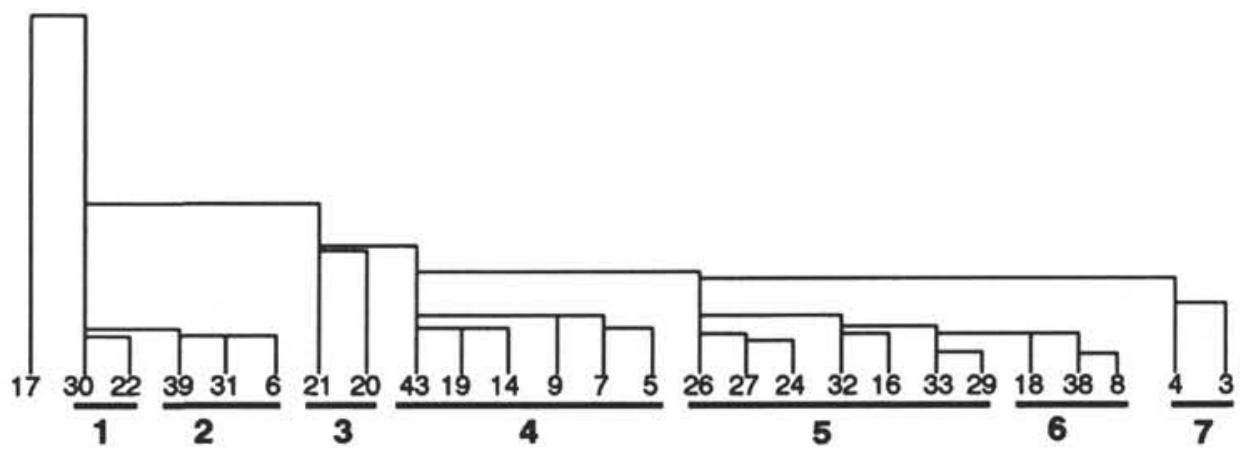

Figure 6. Dendogram showing the result of a clustering analysis with $\mathrm{Cs} / \mathrm{Rb}, \mathrm{Ba} / \mathrm{Rb}, \mathrm{La} / \mathrm{Rb}, \mathrm{Ce} / \mathrm{Rb}, \mathrm{Ta} / \mathrm{Rb}, \mathrm{Th} / \mathrm{Rb}$, and $\mathrm{U} / \mathrm{Rb}$ as primary data. The data were normalized by subtracting the average element ratio and dividing this difference by the element concentration. The clusters are numbered sequentially from one to seven. The numbers identifying the layers refer to Tables 1 and 3 .

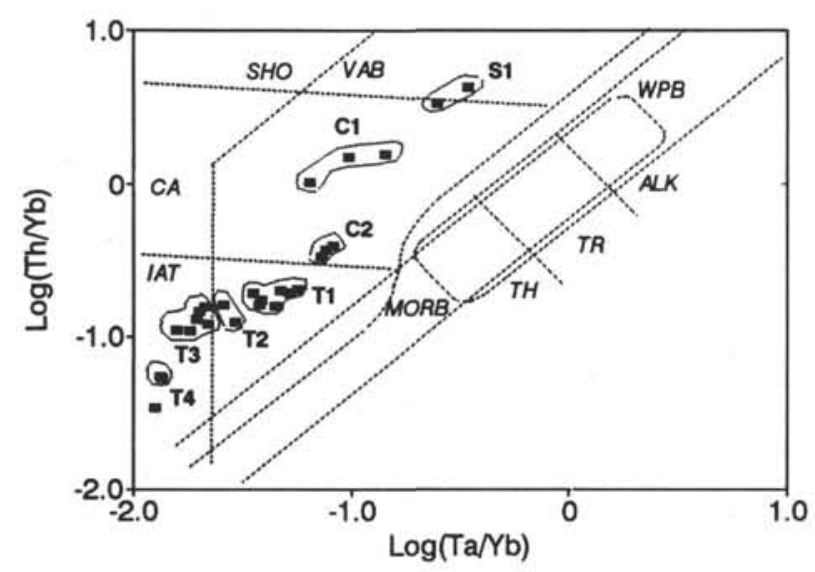

Figure 7. $\mathrm{Th} / \mathrm{Yb}$ vs. $\mathrm{Ta} / \mathrm{Yb}$ in glass shards isolated from tephras in Holes $792 \mathrm{~A}$ and 792E (after Pearce et al., 1981). MORB = mid-ocean-ridge basalt, WPB $=$ within-plate basalt, $\mathrm{VAB}=$ volcanic-arc basalt, $\mathrm{TH}=$ tholeitic, $\mathrm{TR}=$ transitional, $\mathrm{ALK}=$ alkaline, $\mathrm{CA}=$ calc-alkaline, $\mathrm{SHO}=$ shoshonitic, and IAT $=$ island-arc tholeiite. The grouping indicated by the enveloping lines is the same as in Figure 6 (see Table 3 for key).

front. Recently, this simplistic picture was modified by Stern et al. (1988), who found that shoshonitic volcanism may characterize the initial stages of arc construction after an episode of backarc rifting.

The volcanoes of the Izu Islands may be classified into two groups (Onuma et al., 1983; Notsu et al., 1983). The first group consists of the volcanoes situated on the volcanic front (Oshima, Omurodashi, Miyakejima, Mikurajima, Hachijojima, Aogashima, Torishima, and Sofugan). The second group consists of the volcanoes situated behind the volcanic front (Toshima, Udonejima, Niijima, Shikinejima, Kozushima, Onoharajima, and Inambajima) (Fig. 1). In accordance with the scheme of Jakes and White (1972), the volcanoes on the front are dominated by tholeiitic series whereas those behind the front are dominated by calc-alkaline series (Onuma et al., 1983). This will be used as the first-order criterion for correlation.

Compared with the Mariana and Volcano arcs, surprisingly little work has been done on the distribution of trace elements and REEs in the Izu-Ogasawara Arc. The only trace elements that have been systematically mapped are $\mathrm{Ba}$ and $\mathrm{Sr}$ (Onuma et al., 1981; Isshiki et al., 1982; Hirano et al., 1982). The $\mathrm{Ba} / \mathrm{Sr}$ ratio will be used as the second-order criterion for correlation. However, this ratio is not fractionation independent. Judging from the pronounced Ti depletion

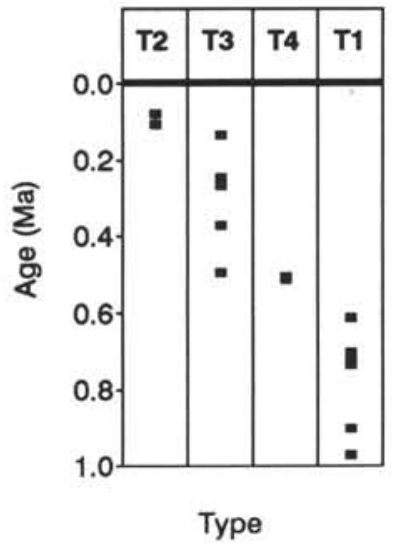

Figure 8. Changes in the tholeiitic magma series affinities of glass shards isolated from tephras in Holes 792A and 792E during the last 1.0 m.y.

(Figs. 9A and 9B) and because the ash layers come from explosive volcanism, they probably represent highly differentiated compositions. Thus, this ratio is not ideal for correlation purposes. Nevertheless, because of the scarcity of other data, this is our best option.

Figure 12 compares the distribution of $\mathrm{Ba} / \mathrm{Sr}$ ratios along the northern part of the Izu-Ogasawara Arc with the $\mathrm{Ba} / \mathrm{Sr}$ ratios of the four tholeiitic, two calc-alkaline, and shoshonitic groups. The correlation of the various groups will be discussed separately.

\section{Correlation of the Tholeiitic Layers}

All of the tholeiitic layers except for Layer 43 are less than 1 m.y. old. Our first criterion dictates that these layers must derive from volcanoes on the volcanic front. Only volcanoes on Oshima and Hachijojima have produced tholeiites with sufficiently high $\mathrm{Ba} / \mathrm{Sr}$ ratios to be source candidates (Fig. 12). Of these, Hachijojima is more probable because of its proximity to Site 792 . However, the high $\mathrm{Ba} / \mathrm{Sr}$ in the tholeiitic ashes relative to the lava analyses may reflect missing samples of extremely differentiated compositions on the islands.

Notsu et al. (1983) observed a remarkably narrow range of strontium isotope ratios in Quaternary volcanic rocks from the Izu-Ogasawara Arc (0.7033-0.7038). When including data from other sources (Kurasawa, 1979; Stern, 1982; Nohda and Wasserburg, 1981; Ikeda and Yuasa, 1989; Hochstaedter et al., 1990), this range only expands to $0.7032-0.7040$. $\mathrm{The}^{87} \mathrm{Sr}{ }^{86} \mathrm{Sr}$ values of the tholeiitic layers plot within or very close to this range (Fig. 13). 
A
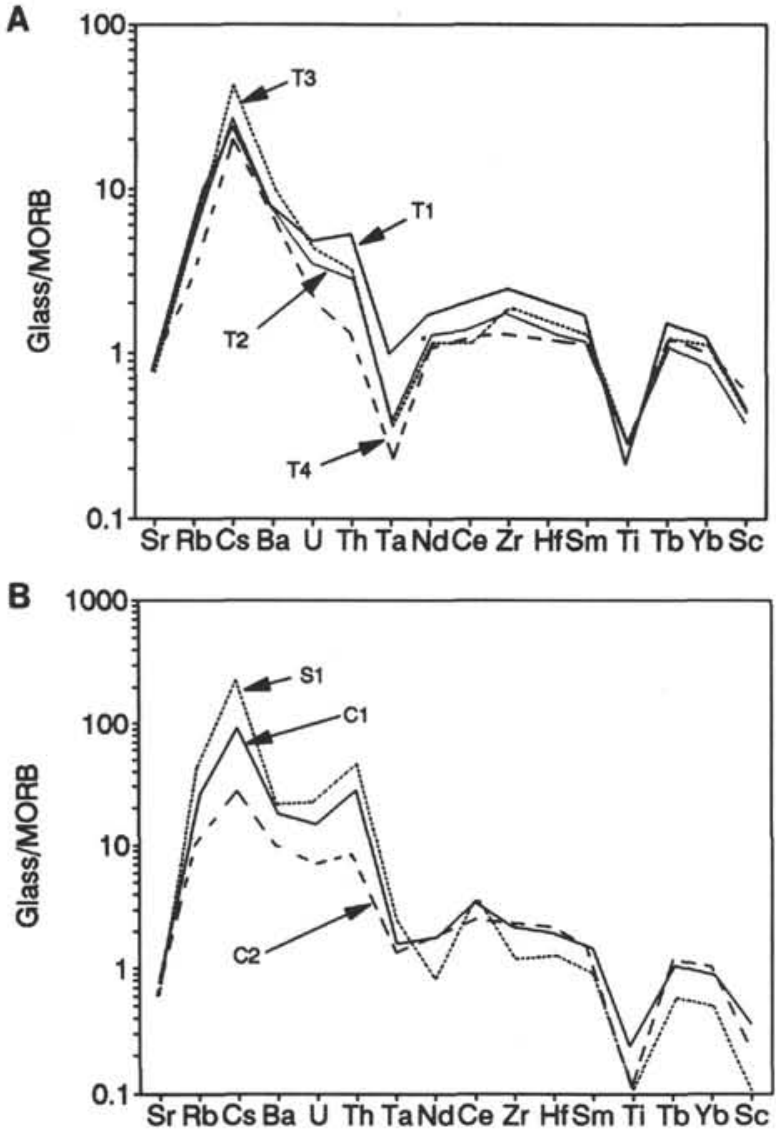

Figure 9. LIL-HFS diagrams averaged for each of the tholeiitic groups (A) and the calc-alkaline and shoshonitic groups (B) (modified from Pearce et al., 1981). The N-MORB data for normalization were taken from table 11.6 of Taylor and McLennan (1985), except for $\mathrm{Yb}$, which is about $36 \%$ too high compared with the other heavy REEs.

\section{Correlation of the Calc-alkaline Layers}

The calc-alkaline layers span a period of 6.25 m.y. Based on the first criterion, these must derive from volcanoes behind the volcanic front. Only volcanoes on Kozushima and Niijima have produced calc-alkaline series with sufficiently high $\mathrm{Ba} / \mathrm{Sr}$ ratios to be considered as sources (Fig. 12) (the uncertainty with respect to the coverage of the island samples must be kept in mind).

On the other hand, the ${ }^{87} \mathrm{Sr} /{ }^{86} \mathrm{Sr}$ values of the $\mathrm{C} 1$ layers are considerably higher than ever reported for volcanism along the Izu-Ogasawara Arc (Fig. 13). These layers must have been derived from outside the arc. To the south of the Izu-Ogasawara Arc lie the Volcano and Mariana arcs (Fig. 1). Except for the old data published by Pushkar (1968), there are no reports of volcanism from the Mariana Arc with ${ }^{87} \mathrm{Sr} /{ }^{86} \mathrm{Sr}$ values higher than 0.70362 (Woodhead and Fraser, 1985). The highest ${ }^{87} \mathrm{Sr} /{ }^{86} \mathrm{Sr}$ value reported from the Volcano Arc is 0.70387 (Stern et al., 1984). On the other hand, the Ryukyu Arc volcanoes Kikai, Sakurajima, and Kirishima (Fig. 1) have ${ }^{87} \mathrm{Sr}{ }^{\beta 6} \mathrm{Sr}$ values of $0.70485-0.70539$ (Notsu and Tatsunori Soya, 1987), 0.7051-0.7058 (Kurasawa et al., 1984), and 0.7045-0.7069 (Kurasawa et al., 1986), respectively. Most of the volcanoes from central Japan have ${ }^{87} \mathrm{Sr} /{ }^{86} \mathrm{Sr}$ ratios (Notsu et al., 1989) that are too radiogenic to be regarded as sources for the $\mathrm{Cl}$ layers. These facts favor derivation of the $\mathrm{Cl}$ group layers from volcanoes on the Ryukyu Arc.

\section{Correlation of the Shoshonitic Layers}

The shoshonitic layers are 0.52 and 0.86 m.y. old. Jakes and White (1972) suggested that when shoshonitic rocks occur the age of the basement rocks is usually pre-Mesozoic. The evolution of the IzuOgasawara Arc is thought to have begun in the early-middle Eocene. Stern et al. (1988) found that shoshonitic volcanism may also be produced during the initial stage of arc construction following an episode of backarc rifting, and recently Lin et al. (1989) have in fact reported the occurrence of shoshonitic volcanism in the northern Mariana Arc. However, the high ${ }^{87} \mathrm{Sr} /{ }^{86} \mathrm{Sr}$ values of the shoshonitic layers (Fig. 13) show that they cannot have been derived from the Izu-Ogasawara, Volcano, or Mariana arcs. In a comparison of volcanism along the three Japanese arcs, Aramaki and Ui (1982) found that $\mathrm{K}_{2} \mathrm{O}$-rich $(2.5 \%-4.5 \%)$ ash-fall deposits associated with large calderas occur almost exclusively in the southwest Japan Arc (southwest Honshu and Ryukyu arcs). For this reason, the Ryukyu Arc volcanoes are the most likely sources of shoshonitic layers.

\section{CONCLUSIONS}

Glass shards from 26 megascopic tephras have been analyzed for 26 elements and ${ }^{87} \mathrm{Sr} /{ }^{86} \mathrm{Sr}$ and ${ }^{143} \mathrm{Nd} /{ }^{144} \mathrm{Nd}$ isotope ratios. The following three points were addressed: (1) the degree of alteration of the samples, (2) chemical characterization in a tectonic context, and (3) correlation of the tephras with volcanism along the Izu-Ogasawara and Ryukyu arcs.

The most important observations of our study are:

1. The distribution of ${ }^{87} \mathrm{Sr} /{ }^{86} \mathrm{Sr}$ and ${ }^{143} \mathrm{Nd} /{ }^{144} \mathrm{Nd}$ isotope ratios indicate that the glass separates contain less than $10 \%$ of palagonitized glass or secondary alteration minerals.

2. All tephras derive from destructive plate margins.

3. Correlation diagrams and cluster analyses show that the tephras may be grouped into four tholeiitic groups, two calc-alkaline groups, and one group with glass of shoshonitic affinity.

4. The grouping obtained by cluster analyses of the "more-HYG" element ratios is also reflected in the distribution of the ${ }^{87} \mathrm{Sr} /{ }^{86} \mathrm{Sr}$ ratios.

5. The tholeiitic groups form a time series, but judging from the REE patterns and the temporal variations of the $\mathrm{Ce} / \mathrm{Yb}$ ratios, the evolution is not unidirectional from strong to weak tholeiitic affinity.

6. The tholeiitic layers were derived from volcanoes on the IzuOgasawara Arc, most probably from the volcanic island Hachijojima. Only one group of the calc-alkaline layers can have derived from the Izu-Ogasawara Arc. The other calc-alkaline layers and the two layers with shoshonitic affinity probably derive from volcanism along the Ryukyu Arc.

\section{ACKNOWLEDGMENTS}

This study was funded by the Norwegian Research Council for Science and the Humanities (NAVF). I also thank the Leg 126 technical staff. Special thanks go to Ms. Toril Enger at the Mineralogisk Geologisk Museum for conducting the chemical preparations for the mass spectometry.

\section{REFERENCES}

Ailin-Pyzik, I. B., and Sommer, S. E., 1981. Microscale chemical effects of low temperature alteration of DSDP basaltic glasses. J. Geophys. Res., 86:9503-9510.

Anders, E., and Grevesse, N., 1989. Abundances of the elements: meteoritic and solar. Geochim. Cosmochim. Acta, 53:197-214.

Aramaki, S., and Ui, T., 1982. Japan. In Thorpe, R. S. (Ed.), Andesites: New York (Wiley), 259-292.

Faure, G., 1986. Principles of Isotope Geology: New York (Wiley).

Fisher, R. V., and Schmincke, H.-U., 1984. Pyroclastic Rocks: Berlin (Springer-Verlag).

Fujioka, K. F., Cadet, J.-P., and Morin, J.-C., 1986. Volcanic ash at Site 584, Japan Trench. In Kagami, H., Karig, D. E., Coulbourn, W. C., et al., Init. Repts. DSDP, 87: Washington (U.S. Govt. Printing Office), 681-694. 

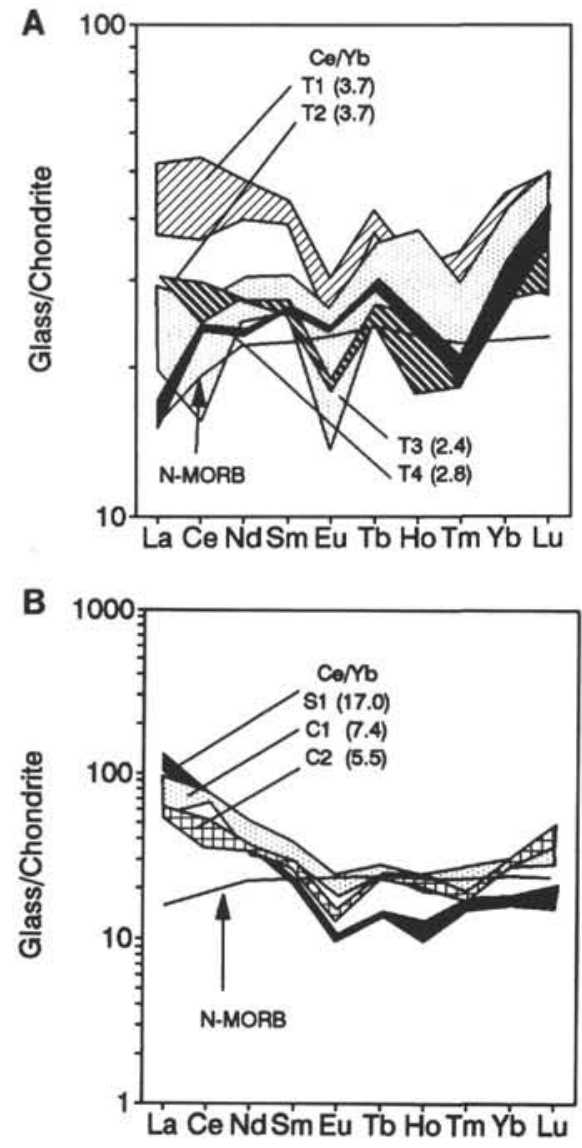

Figure 10. Chondrite-normalized REE patterns for the tholeiitic groups (A) and the calc-alkaline and shoshonitic groups (B). Because of instrumental difficulties, some of the REE analyses are suspect. The following analyses are not included in Figure 10A: La (Samples 3 and 9), Ce (Sample 26), and Eu (Sample 29). The N-MORB data are taken from table 11.6 of Taylor and McLennan (1985), except for $\mathrm{Yb}$, which is about $36 \%$ too high compared with the other heavy REEs. Chondrite concentrations are from Anders and Grevesse (1989).

Furnes, H., 1980. Chemical changes during palagonitization of an alkaline olivine basaltic hyaloclastite, Santa Maria, Azores. Neues Jahrb. Mineral. Abh., 138:14-30.

Furuta, T., and Arai, F., 1980. Petrographic and geochemical properties of tephras in Deep Sea Drilling project cores from the North Philippine Sea. In Klein, G. deV., Kobayashi, K., et al., Init. Repts. DSDP, 58: Washington (U.S. Govt. Printing Office), 617-625.

Hirano, M., Isshiki, N., and Onuma, N., 1982. Sr/Ca-Ba/Ca systematics in Miyakejima, Onoharajima, Mikurajima and Inambajima volcanoes, the Izu Islands, Japan. Geochem. J., 16:79-87.

Hochstaedter, A. G., Gill, J. B., and Morris, J. D., 1990. Volcanism in the Sumisu Rift II. Subduction and non-subduction related components. Earth Planet. Sci. Lett., 100:195-209.

Ikeda, Y., and Yuasa, M., 1989. Volcanism in nascent back-arc basins behind the Shichito Ridge and adjacent areas in the Izu-Ogasawara Arc, northwest Pacific: evidence for mixing between E-type MORB and island arc magmas at the initiation of back-arc rifting. Contrib. Mineral. Petrol., 101:377-393.

Isshiki, N., Onuma, N., and Hirano, M., 1982. Sr/Ca-Ba/Ca systematics of Quaternary volcanoes in Toshima, Udonejima, Niijima, and Kozushima, the Izu Islands, Japan. Geochem. J., 16:119-127.

Jakes, P., and White, J. R., 1972. Major and trace element abundances in volcanic rocks of orogenic areas. Geol. Soc. Am. Bull., 83:29-39.

Joron, J.-L., and Treuil, M., 1977. Utilisation des proprietes des elements fortement hygromagmatophiles pour l'etude de la composition chimique et de l'heterogeneite du manteau. Bull. Geol. Soc. Fr., 19:1197-1205.

Kennett, J. P., 1981. Marine tephrochronology. In Emiliani, C. (Ed.), The Sea (Vol. 7): London (Academic Press), 1373-1436.
Table 3. Classification of layers based on trace element analyses.

\begin{tabular}{lccl}
\hline $\begin{array}{c}\text { Group } \\
\text { (Fig. 7) }\end{array}$ & Abbreviation & $\begin{array}{c}\text { Cluster } \\
\text { (Fig. 6) }\end{array}$ & \multicolumn{1}{c}{ Layers in each group } \\
\hline Shoshonitic & S1 & 1 & 22,30 \\
Calc-alkaline & C1 & 2 & $6,31,39$ \\
& C2 & 6 & $8,18,38$ \\
Tholeiitic & T1 & 5 & $16,24,26,27,29,32,33$ \\
& T2 & 7 & 3,4 \\
& T3 & 4 & $5,7,9,14,19,43$ \\
& T4 & 3 & 20,21 \\
\hline
\end{tabular}

Kurasawa, H., 1979. Isotopic composition of strontium in volcanic rocks from Fuji, Hakone, and Izu area, Central Japan. Bull. Volcanol. Soc. Jpn., 24:135-152.

Kurasawa, H., Arai, F., and Machida, H., 1984. Strontium isotopic identification of the widespread Aira-Tn ash-fall deposits (AT) in Japan. Kazan, Ser. II, 29:115-118.

Kurasawa, H., Fujinawa, A., and Leeman, W. P., 1986. Calc-alkaline and tholeiitic rock series magmas coexisting within volcanoes in Japanese island arcs-strontium isotopic study. J. Jpn. Geol. Soc., 92:255-268.

Lin, P.-N., Stern, R. J., and Bloomer, S. H., 1989. Shoshonitic volcanism in the northern Mariana Arc 2. Large-ion lithophile and rare earth element abundances: evidence for the source of incompatible element enrichments in intraoceanic arcs. J. Geophys. Res., 94:4494-4514.

Lin, P.-N., Stern, R. J., Morris, J., and Bloomer, S. H., 1990. Nd- and $\mathrm{Sr}$-isotopic compositions of lavas from the northern Mariana and southern Volcano arcs: implications for the origin of island arc melts. Contrib. Mineral. Petrol., 105:381-392.

Machida, H., 1981. Tephrochronology and Quaternary studies in Japan. In Self, S., and Sparks, S. (Eds.), Tephra Studies: London (D. Reidel), 161-191.

Mearns, E. W., 1986. Sm-Nd ages for Norwegian garnet Peridotite. Lithos, 19:269-278.

Migdisov, A. A., Miklishansky, A. Z., Saveliev, B. V., Bredanova, N. V., Girin, Y. P., Pavlutskaya, V. I., and Yakovlev, Y. V., 1981. Neutron activation analysis of rare earth elements and some other trace elements in volcanic ashes and pelagic clays, Deep Sea Drilling Project Leg 59. In Kroenke, L., Scott, R., et al., Init. Repts. DSDP, 59: Washington (U.S. Govt. Printing Office), 653-668.

Neumann, E.-R., Tilton, G. R., and Tuen, E., 1988. Sr, Nd and Pb isotope geochemistry of the Oslo rift igneous province, southeast Norway. Geochim. Cosmochim. Acta., 52:1997-2007.

Nohoda, S., and Wasserburg, G. J., 1981. Nd and Sr isotopic study of volcanic rocks from Japan. Earth Planet. Sci. Lett., 52:264-276.

Notsu, K., Arakawa, Y., Nakano, S., and Yamasaki, M., 1989. Lateral variation in ${ }^{87} \mathrm{Sr}{ }^{86} \mathrm{Sr}$ ratios of volcanic rocks from central Japan. Geochem. J., 23:45-55.

Notsu, K., Isshiki, N., and Hirano, M., 1983. Comprehensive strontium isotope study of Quaternary volcanic rocks from the Izu-Ogasawara Arc. Geochem. J., 17:289-302.

Notsu, K., and Tatsunori Soya, K. O., 1987. Strontium isotopic relations of bimodal volcanic rocks at Kiaki volcano in the Ryukyu Arc, Japan. Geology, 15:345-348.

Onuma, N., Hirano, M., and Isshiki, N., 1981. Sr/Ca-Ba/Ca systematics in four volcanoes of Oshima, Izu Islands, Japan. Geochem. J., 15:315-324.

, 1983. Genesis of basalt magmas and their derivatives under the Izu Islands, Japan, inferred from $\mathrm{Sr} / \mathrm{Ca}-\mathrm{Ba} / \mathrm{Ca}$ systematics. $J$. Volcanol. Geotherm. Res., 18:511-529.

Packham, G. H., and Williams, K. L., 1982. Volcanic glasses from sediments from Sites 453 and 454 in the Mariana through. In Hussong, D. M., Uyeda, S., et al., Init. Repts. DSDP, 60: Washington (U.S. Govt. Printing Office), 483-495.

Pearce, J. A., Alabaster, T., Shelton, A. W., and Searle, M. P., 1981. The Oman ophiolite as a Cretaceous arc-basin complex: evidence and implications. Philos. Trans. R. Soc. London A, 300:299-317.

Pouclet, A., Fujioka, K., Charvet, J., and Cadet, J.-P., 1986. Petrography and geochemistry of volcanic ash layers from Leg 87A, Nankai Trough (South Japan), In Kagami, H., Karig, D. E., et al., Init. Repts. DSDP, 87: Washington (U.S. Govt. Printing Office), 695-701.

Pushkar, P., 1968. Strontium isotope ratios in volcanic rocks of three island arc areas. J. Geophys. Res., 73:2701-2714.

Scheidegger, K. F., Corliss, J. B., Jezek, P. A., and Ninkovich, D., 1980. Composition of deep-sea ash layers derived from north Pacific volcanic arcs: variations in time and space. J. Volcanol. Geotherm. Res., 7:107-137. 


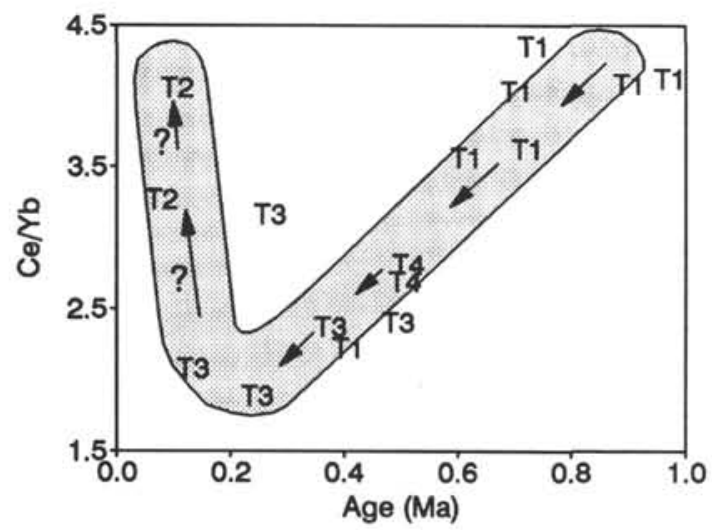

Figure 11. $\mathrm{Ce} / \mathrm{Yb}$ for the individual tholeiitic layers vs. time since deposition. The shaded area represents the evolution from tholeiitic compositions (T1) to less tholeitic compositions (T3), and possibly a return to more tholeiitic compositions in the younger layers (T2).

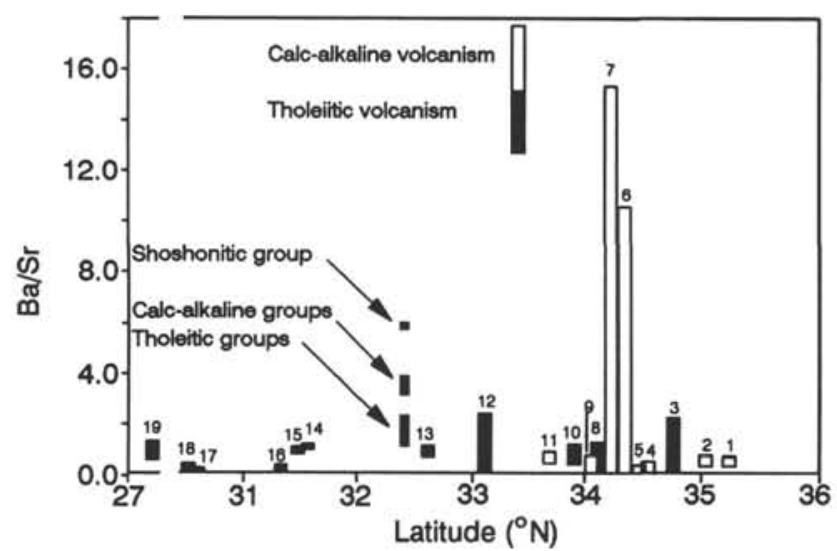

Figure 12. $\mathrm{Ba} / \mathrm{Sr}$ data in ejecta from volcanoes along the Izu-Ogasawara Arc compared with the $\mathrm{Ba} / \mathrm{Sr}$ ratio for the various groups defined in Table 3. The numbers indicate the location. $1=\mathrm{Mt}$. Fuji, 2 = Hakone, $3=$ Oshima, $4=$ Toshima, 5 = Udoneshima, 6 = Niijima, $7=$ Kozushima, $8=$ Miyakejima, $9=$ Onoharajima, $10=$ Mikurajima, 11 = Inambajima, 12 = Hachijojima, 13-17 = Shichito Ridge, $18=$ Torishima, and $19=$ Nishinoshima. The data are from Onuma et al. (1981, 1983), Isshiki et al. (1982), Hirano et al. (1982), Ikeda and Yuasa (1989), and Lin et al. (1989).

Staudigel, H., and Hart, S. R., 1983. Alteration of basaltic glass: mechanisms and significance of the oceanic crust-seawater budget. Geochim. Cosmochim. Acta, 47:337-350.

Steinnes, E., 1971. Epithermal neutron activation analysis of geological material. In Brunfelt, A. O., and Steinnes, E. (Eds.), Activation Analysis in Geochemistry and Cosmochemistry: Oslo (Universitetsforlaget), 113-128.

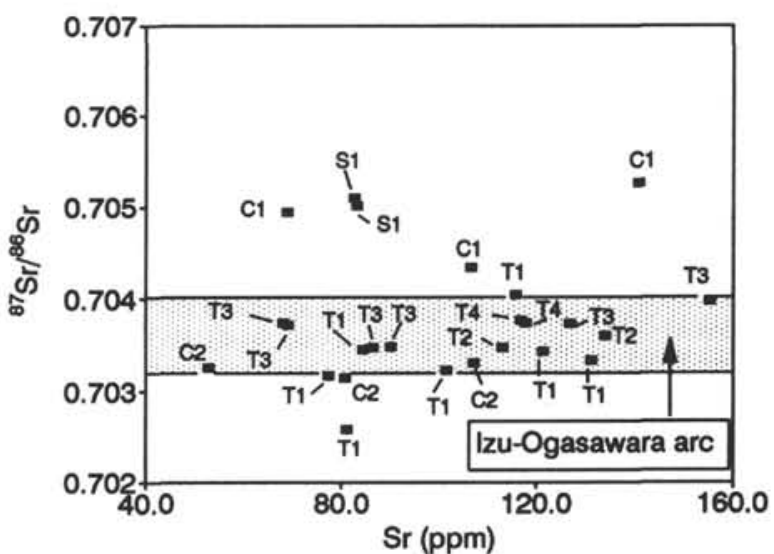

Figure 13. A comparison of the ${ }^{87} \mathrm{Sr} /{ }^{86} \mathrm{Sr}$ values of the glass shards isolated from tephras in Hole 792A and Hole 792E with the range of ${ }^{87} \mathrm{Sr} /{ }^{86} \mathrm{Sr}$ values reported for volcanism along the Izu-Ogasawara Arc (see text).

Stern, R. J., 1982. Strontium isotopes from circum-Pacific intra-oceanic island arcs and marginal basins: regional variations and implications for magmagenesis. Geol. Soc. Am. Bull., 93:477-486.

Stern, R. J., Bloomer, S. H., Ito, E., and Morris, J., 1988. Shoshonitic magmas in nascent arcs: new evidence from submarine volcanoes in the northern Marianas. Geology, 16:426-430.

Stern, R. J., Smoot, N. C., and Rubin, M., 1984. Unzipping of the Volcano Arc, Japan. Tectonophysics, 102:153-174.

Taylor, B., Fujioka, K., et al., 1990. Proc. ODP, Init. Repts., 126: College Station, TX (Ocean Drilling Program).

Taylor, S. R., and McLennan, S. M., 1985. The Continental Crust: Its Composition and Evolution: Oxford (Blackwell Scientific).

Wood, D. A., 1980. The application of a Th-Hf-Ta diagram to problems of tectonomagmatic classification and to establishing the nature of crustal contamination of basaltic lavas of the British Tertiary volcanic province. Earth Planet. Sci. Lett., 50:11-30.

Wood, D. A., Joron, J.-L., and Treuil, M., 1979. A re-appraisal of the use of trace elements to classify and discriminate between magma series erupted in different tectonic settings. Earth Planet. Sci. Lett., 45:326-336.

Woodhead, J. D., and Fraser, D. G., 1985. Pb, Sr, and ${ }^{10} \mathrm{Be}$ isotopic studies of volcanic rocks from the Northern Mariana Islands: implications for magma genesis and crustal recycling in the western Pacific. Geochim. Cosmochim. Acta, 49:1925-1930.

Zielinski, R. A., 1982. The mobility of uranium and other elements during alteration of rhyolitic ash to montmorillonite: a case study in the Troublesome Formation, Colorado. Chem. Geol., 35:185-204.

Date of initial receipt: 15 November 1990

Date of receipt: 9 September 1991

Ms 126B-149 